\title{
Preparation of Anode Material for Lithium Secondary Battery using Pitch-coated Graphite Residue Compounds
}

\author{
Young-Shin Ko^ and Won-Chun $\mathrm{Oh}^{1}$ \\ Division of Common Study, Hanseo University, Chungnam 356-706, Korea \\ ${ }^{1)}$ Department of Advanced Materials \& Science Engineering, Hanseo University, Chungnam 356-706, Korea \\ ‘e-mail: kokoo@hanseo.ac.kr \\ (Received June 30, 2007; Accepted August 16, 2007)
}

\begin{abstract}
The properties and electrochemical characteristics of anode material using pitch-coated graphite residue compounds by heat-treatment at $600^{\circ} \mathrm{C}$ for 1 hour were investigated. The distance of layers of pitch-coated graphite residual compounds was $3.3539 \AA$, which was as same as that of graphite. Its electrochemical and charge-discharge characteristics were tested according to different four types of carbon material, natural graphite, pitch-coated graphite, amorphous graphite and pitch-coated graphite residual compounds, respectively. So it was shown the best charge-discharge characteristics in all of the samples. For the electrochemical and charge-discharge characteristics, although pitch-coated graphite residual compounds had different carbon contents $70 \%$ and $80 \%$, these two samples were shown good electrochemical and charge-discharge characteristics.
\end{abstract}

Keywords : Lithium ion secondary battery, Carbon anode, Graphite residue compounds

\section{1. 서 론}

최근 전자산업의 발달과 함께 휴대용 전자기기의 소형전원 으로 사용하기 위한 경량성이며 고성능인 리틈이차전지의 개 발에 대한 중요성이 부각되고 있다[1]. 특히 $\mathrm{LiMn}_{2} \mathrm{O}_{4}, \mathrm{LiCoO}_{2}$ 나 $\mathrm{LiNiO}_{2}$ 등의 전이금속산화물을 이용한 양극과 탄소재료를 음극으로 사용한 리튬이온전지는 일본 등의 선진국에서 개발 되고 있으며 일부는 실용화 단계에 이르고 있다[2,3]. 또한, 20세기 후반 들어 급격히 발전하고 있는 첨단 전자제품이 소 형화, 경량화되면서 전력원으로 사용되는 전지 또한 이러한 요 구를 충족시키기 위하여 용도에 맞는 다양한 형태의 고성능 전지가 선택되어지고 있으며 한번 사용후에도 재충전하여 계 속 사용이 가능한 이차전지에 대하여 많은 관심을 갖게 되었 다. 재충전 가능한 전기화학적 전력원으로 결정성계 탄소재료 가 사용된 전극은 1938년 Rudorff와 Hoffmann에 의하여 처음 제안되었다[4]. 이차전지 중에서도 리튬 이차전지는 이론상 가 장 높은 기전력을 나타내며 이론 에너지 밀도가 크기 때문에 이의 활용을 위하여 전세계적으로 집중적인 연구가 이루어지 고 있다. 이러한 연구의 흐름과 함께 리틈이온 이차전지의 음극 활물질로서 탄소재료에 대한 관심이 고조되었으나 탄소 재료는 출발물질이 매우 다양하고 처리방법에 따라 그의 물리 적, 전기화학적인 특성이 다르게 나타나므로 이들의 물리적 특 성을 조절하여 전기화학적인 특성을 조절하고자하는 노력들이 계속하여 이루어지고 있다. 리틈이온 이차전지에서 사용되는
탄소 음극은 리틈의 삽입(intercalation)과 탈삽입(deintercalation)을 이용하므로 이들의 반응이 일어나는 동안 host 재료가 되는 탄소재료의 구조는 대단히 중요하며 탄소재료의 구조는 탄소가 갖는 물리적인 특성과 깊은 관련이 있으므로 탄소재료 의 물리적 특성을 효율적으로 조절할 수 있는 연구가 수행되 고 있다 $[5,6]$.

리튬이온 이차전지용 음극 활물질로서 가장 활발히 연구되 어지고 있는 탄소전극재료에는 크게 흑연계 탄소재료와 비졀 정성계 탄소재료로 구분될 수 있다[7-11]. 이중 흑연계 탄소전 극은 탄소의 층상구조가 잘 발달되어 있으며 이들 층간에 리 튬이 이상적으로 삽입되어 $\mathrm{LiC}_{6}$ 를 형성하였을 때 $372 \mathrm{mAh} / \mathrm{g}$ 의 높은 이론 에너지 밀도를 갖는다[12]. 그러나 리튬이온전지 의 전극활물질로 이용한 흑연계 탄소전극의 경우 충-반전이 진행함에 따른 용량감소에 의하여 이론용량 만큼의 에너지를 충분히 활용치 못하고 있어 리튬이차전지의 에너지 이용효율 에 많은 문제점을 지니고 있다.

본 연구에서는 탄소재료 중 흑연구조가 상대적으로 잘 발달 된 흑연을 사용하여 황산 흑연층간화합물을 만들고 이들 수세 하여 흑연 잔유화물을 제조한다. 여기에 저온 탄소체 형성에 유리한 저결정성의 탄소피복재인 사염화탄소 용융법에 의거하 여 피치를 코팅하여 방전용량을 향상시키고자 하는 것이다. 저 결정성의 탄소피복재를 고결정성의 탄소재에 코팅한 후 이를 탄화 및 분쇄하여 리틈이차전지용 음극재료로 상용화 범위내 에서 제어할 수 있는지를 확인하고자 하였다. 


\section{2. 실 험}

\section{1. 시료}

조합형 탄소전극으로 사용된 탄소재료로는 흑연계 탄소재료 로서 흑연(SangJin, Korea) 및 토상흑연(Sangjin, Korea)을 사 용하였고 석유계 피치(Granular pitch, Jungwoo Chemical Co. Korea)를 코팅물질로 사용하였다. 황산 $\left(\mathrm{H}_{2} \mathrm{SO}_{4}, 98 \%\right.$, Daejung Chemical \& Metals Co., Ltd. Korea)을 층간 삽입물질로 사용 하였고 사염화탄소 $\left(\mathrm{CCl}_{4}\right.$, Daejung Chemical \& Metals Co., Ltd. Korea)는 용매로 사용하였다.

\section{2. 실험}

피치 코팅된 흑연잔유화합물의 제조과정을 Fig. 1에 나타내 었다. 황산용액에 산화제인 암모늄 퍼설페이트 $\left(\left(\mathrm{NH}_{4}\right)_{2} \mathrm{~S}_{2} \mathrm{O}_{8}\right)$,

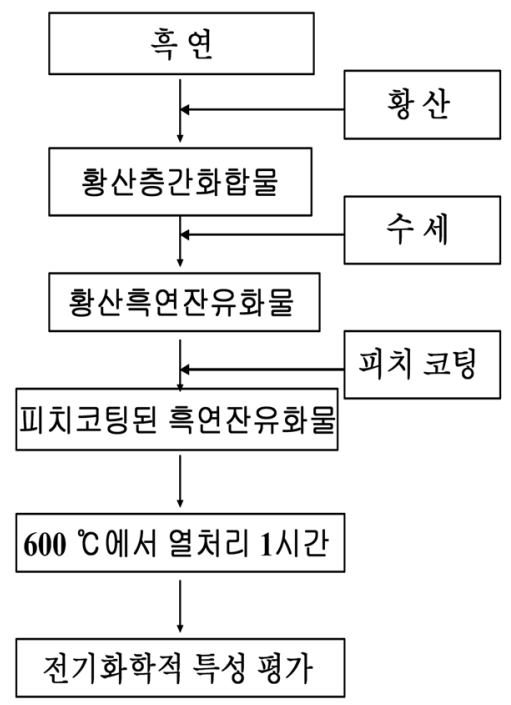

Fig. 1. Preparation procedure of pitch-coated graphite residual compounds.
Daejung Chemical \& Metals Co., Ltd. Korea)를 녹인 후, 선별 하여 얻은 $10 \mu \mathrm{m}$ 이하의 흑연을 상기 용액중에 분산 시키면 수분 후에 흑연이 청색으로 변화함과 동시에 황산-흑연층간화 합물이 제조된다. 이와 같이 제조된 화합물은 일부의 황산을 제거하기위하여 수중에서 48 시간동안 저어주면서 세척한다. 이결과 잔유 화합물이 형성된다. 석유계 피치를 $60 \sim 80^{\circ} \mathrm{C}$ 의 범 위에서 사염화탄소 용매를 사용하여 용융한다. 용매속에서 용 융된 피치를 $5 \mu \mathrm{m}$ 이하의 황산 흑연 잔유 화합물을 코팅 처 리한다. 상기방법으로 얻어진 전구체 피치 코팅된 황산 흑연 잔유화합물은 $600^{\circ} \mathrm{C}$ 이상에서 탄화처리하여 부극용 탄소재를 얻어 내었다. 이때 프리커서 토상흑연의 고정탄소량이 $78 \%$ 인 것을 “흑연 78”이라 명명하였으며, 또한 프리커서 토상흑연의 고정탄소량이 $80 \%$ 인 것을 “흑연 80 ”이라 명명하였다.

\section{3. 특성 분석}

제조된 흑연 잔유화물과 피치 코팅된 흑연 잔유화물 결정구 조 특성을 조사하기 위하여 시료의 X-선 회절분석을 DebyeScherrer 법에 의거하여 실시하였다. 회절분석에 사용된 X-선 은 Co-filter로 단색화시킨 $\mathrm{CuK \alpha} \alpha_{1}(1.54050 \AA)$ 선이었으며 이때 의 전압과 전류는 $20 \mathrm{kV}, 15 \mathrm{~mA}$ 였다. 전자주사 현미경(SEM) (JSM5200, JOEL, JAPAN)을 사용하여 원료시료 및 코팅원료 의 상태와 이들의 표면상태 및 동공구조를 관찰하기 위하여 사용되었다.

\section{4. 음극의 충/방전 특성}

개발된 양극 및 음극물질의 성능을 시험하는 한편 전지 제 조 공정의 최적화를 위하여 Paper type 전지를 제작평가하였 다. Table 1에 paper type 전지의 제조 공정을 나타내었으며, 공정은 크게 slurry 제조, 전극 제작, 전지조립 과정으로 구분 할 수 있으며, 이 공정 중에서 전지의 성능인 용량과 수명(충 방전 cycle수)에 가장 큰 영향을 미치는 전극 제작 공정의 최 적화에 비중을 두고 연구를 수행하였다.

Table 1. Preparation process of lithium secondary battery

\begin{tabular}{|c|c|}
\hline Procedure & Preparation Methods \\
\hline $\begin{array}{l}\text { 부극 제조 } \\
\text { (Anode slurry) }\end{array}$ & $\begin{array}{l}\text { 활물질 (피치가 코팅된 황산-흑연 잔유화합물)을 NMP 용매에 용해된 PVDF와 일정비로 혼합하여 제조 } \\
\text { 하였다. }\end{array}$ \\
\hline 정극 제조 & 리튬 박막을 사용하였다. \\
\hline 부극 제조 & $\begin{array}{l}\text { 혼합된 부극 합제를 폭 } 200 \mathrm{~mm} \text { 두께 } 10 \mu \mathrm{m} \text { 의 구리 박막 위에 Doctor blade를 이용하여 정극과 같은 방 } \\
\text { 법으로 제조 }\end{array}$ \\
\hline 전지제조 & $\begin{array}{l}\text { 1. 정극과 부극을 정해진 크기로 재단한 후 } \mathrm{Ni} \text { 단자를 current collector에 용접 } \\
\text { 2. Separator로 사용하는 Hoechst사의 Cellgard } 2400 \text { 을 정해진 크기로 재단 } \\
\text { 3. Heat sealing이 가능한 } \mathrm{Al} \text { 에 폴리머를 lamination한 재료를 재단하여 봉투 제작 } \\
\text { 4. 전극과 부극사이에 separator를 삽입한 전극을 봉투에 넣은 후 heat seal } \\
\text { 5. 전해액 }\left(1 \mathrm{M} \mathrm{LiPF}_{6} / \text { Ethylene carbonate + dimethyl carbonate }(1: 1 \text { volume\%) 주입 }\right.\end{array}$ \\
\hline
\end{tabular}


Table 2. Analytical results of petroleum pitch

\begin{tabular}{|c|c|c|c|c|c|c|c|c|}
\hline \multirow{2}{*}{ 밀도 } & \multirow{2}{*}{ 연화점 } & \multicolumn{4}{|c|}{ 원소분석 } & \multirow{2}{*}{$\begin{array}{l}\text { 톨루엔 } \\
\text { 불용분 }\end{array}$} & \multirow{2}{*}{$\begin{array}{l}\text { 퀴놀린 } \\
\text { 불용분 }\end{array}$} & \multirow{2}{*}{ 코크수율 } \\
\hline & & 탄소 & 수소 & 질소 & 황 & & & \\
\hline 1.27 & 116 & 92.5 & 4.67 & 1.10 & 0.46 & 41.0 & 8.3 & 42.8 \\
\hline
\end{tabular}

Table 3. Properties of petroleum pitch

\begin{tabular}{cc}
\hline 특성 항목 & 특성치의 범위 \\
\hline 연화점(환구법) $\left({ }^{\circ} \mathrm{C}\right)$ & $80 \sim 116$ \\
비중 $\left(25^{\circ} \mathrm{C}\right)$ & $1.28 \sim 1.32$ \\
탄화율 $(\%)$ & $55 \sim 65$ \\
벤젠 불용분 $(\%)$ & $30 \sim 41$ \\
quinoline 불용분 $(\%)$ & $8 \sim 16$ \\
$\mathrm{C} / \mathrm{H}$ (원자비) & $1.70 \sim 1.85$ \\
약 $500 \mathrm{cP}$ 의 점도를 나타내는 온도 $\left({ }^{\circ} \mathrm{C}\right)$ & $150 \sim 180$ \\
\hline
\end{tabular}

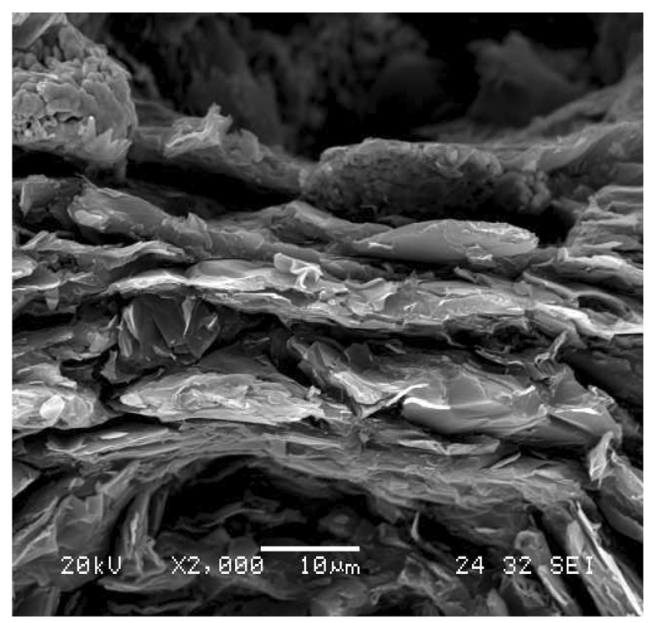

(a)

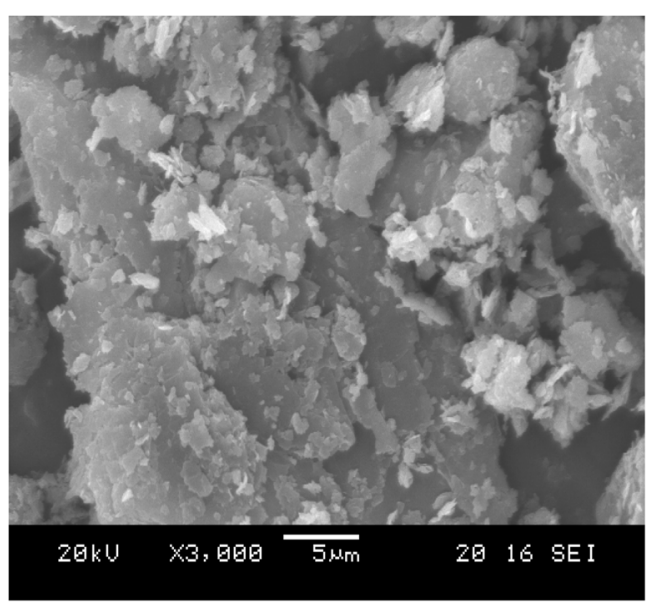

(c)

\section{3. 결과 및 고찰}

\section{1. 원료특성 및 충간 화합물 특성분석}

본 연구에 사용된 석유계 피치의 특성은 다음과 같은 결과 를 얻었다. 음극재료로써 특성에 잘 부합되는 것으로 여겨진 다. Table 2와 3에 나타낸 바와 같이, 석유 잔사유에서 얻어지 므로 가능하면 황이나 질소 성분이 적으면 이상적인 코팅용 피치로 여겨진다. 흑연의 종류와 음극용 탄소재료의 최적구조 는 분명하게 밝혀지지 않으므로 향후 탄소재료를 포함하는 부 극의 성질을 충분하게 연구하여 전극성능에 영향을 주는 인자

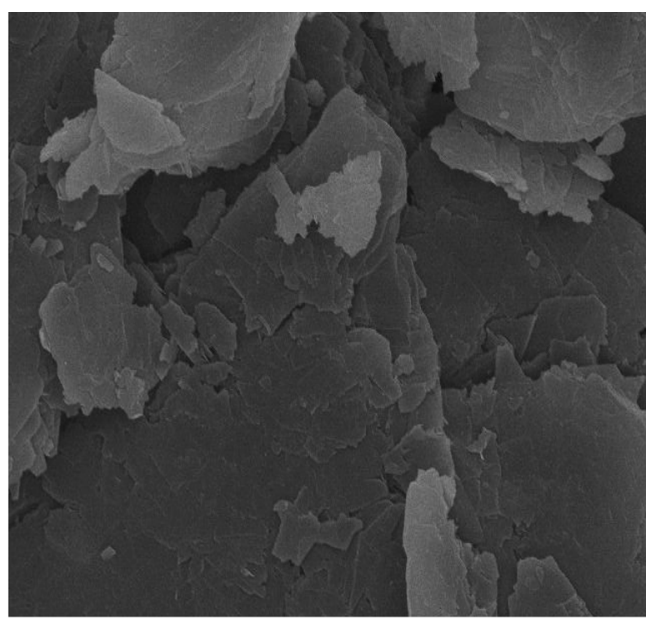

(b)

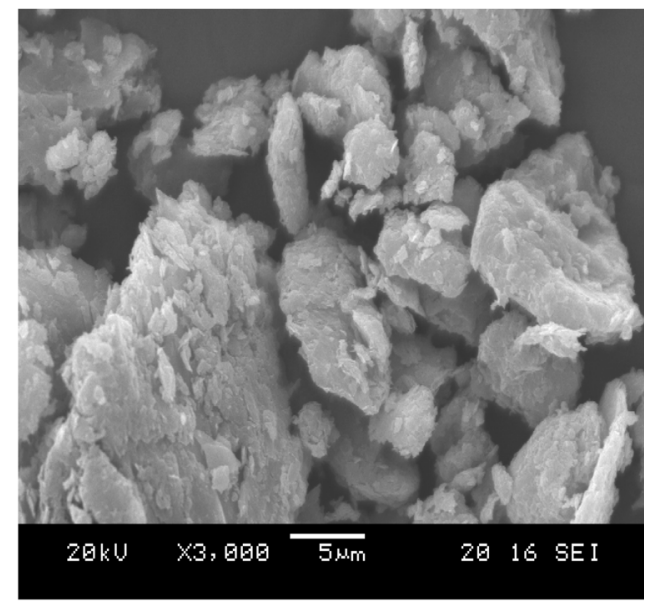

(d)

Fig. 2. SEM micrographs of graphite $(a, b \times 2000)$ and pitch-coated graphite residual compounds $(c, d \times 3000)$. 
Table 4. XRD values of graphite residue compounds

\begin{tabular}{cccccc}
\hline $4 \theta$ & $\theta$ & $\sin \theta$ & $\mathrm{d}(\AA)$ & $(\mathrm{hkl})$ & Intensity \\
\hline 50.670 & 12.668 & 0.2193 & 3.5126 & 5 s 006 & $\mathrm{~V} . \mathrm{S}$ \\
59.420 & 14.855 & 0.2564 & 3.0045 & $4 \mathrm{~s} 006$ & $\mathrm{M}$ \\
63.162 & 15.791 & 0.2721 & 2.8307 & $2 \mathrm{~s} 004$ & $\mathrm{~W}$ \\
85.025 & 21.256 & 0.3625 & 2.1247 & $\mathrm{G} 100$ & $\mathrm{~S}$ \\
87.630 & 21.908 & 0.3731 & 2.0645 & $3 \mathrm{~s} 007$ & $\mathrm{M}$ \\
90.160 & 22.540 & 0.3833 & 2.0095 & $1 \mathrm{~s} 004$ & $\mathrm{~S}$ \\
114.41 & 28.603 & 0.4787 & 1.6090 & $1 \mathrm{~s} 005$ & $\mathrm{M}$ \\
155.18 & 38.795 & 0.6265 & 1.2294 & $\mathrm{G} 110$ & $\mathrm{~S}$ \\
165.02 & 41.255 & 0.6594 & 1.1681 & $\mathrm{G} 112$ & $\mathrm{M}$ \\
170.96 & 42.740 & 0.6787 & 1.1350 & $3 \mathrm{~s} 0013$ & $\mathrm{~V} . \mathrm{W}$ \\
174.95 & 43.738 & 0.6914 & 1.1142 & $4 \mathrm{~s} 0016$ & $\mathrm{~W}$ \\
\hline
\end{tabular}

*1s: Stage 1, 3s: Stage 3, 4s: stage 4, 5s: Stage 5, G: Graphite **V.S: Very Strong, S: Strong, M: Middle, W: Weak, V.W: Very Weak

를 규명하는 것이 필요하다. 특히 천연 흑연의 경우, 판상의 구조를 가지고 있으므로 Fig. 2의 (a)와 (b)에 나타낸 바와 같 이 결합제를 사용하여 평면 도포를 하였을 경우, 한쪽 면으로 의 배향성을 가지므로 2 차 전지의 음극재로로 사용하였을 경 우, 리튬의 저장 용량에 상당한 영향을 주고 있다.

이차전지의 메커니즘은 서론에서도 설명한바와 같이 흑연의

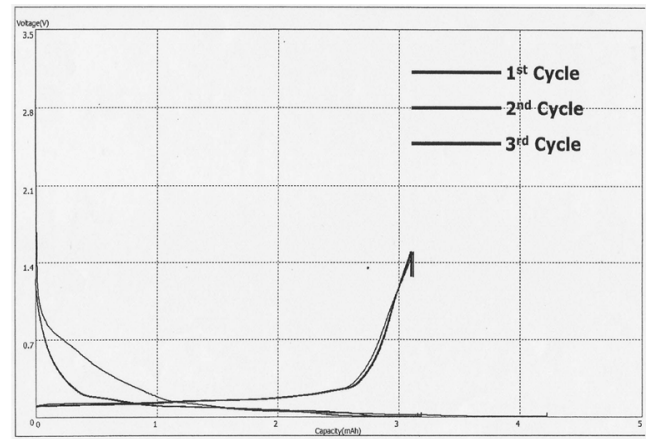

(a)

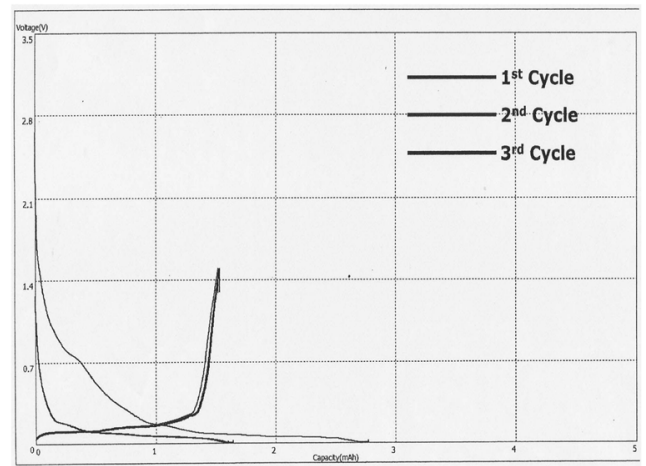

(c)
Table 5. XRD values of pitch-coated graphite residue compounds

\begin{tabular}{cccccc}
\hline $4 \theta$ & $\theta$ & $\sin \theta$ & $\mathrm{d}(\AA)$ & $(\mathrm{hkl})$ & Intensity \\
\hline 53.110 & 13.278 & 0.2297 & 3.3539 & G 002 & V.S-D \\
84.860 & 21.215 & 0.3619 & 2.1286 & G 100 & $\mathrm{M}$ \\
89.150 & 22.289 & 0.3793 & 2.0310 & G 101 & $\mathrm{~S}$ \\
110.46 & 27.615 & 0.4635 & 1.6618 & G 004 & V.W \\
119.74 & 29.935 & 0.4990 & 1.5436 & G 103 & V.W \\
155.11 & 38.778 & 0.6263 & 1.2299 & G 110 & S \\
167.94 & 41.985 & 0.6689 & 1.1515 & G 112 & M \\
174.60 & 43.650 & 0.6903 & 1.1159 & G 006 & W \\
\hline
\end{tabular}

*G: Graphite

**V.S: Very Strong, S: Strong, M: Middle, W: Weak, V.W: Very Weak, D: Diffuse

층간에 리틈의 삽입과 탈삽입과정에 의해 전기적으로 작용하 여 전자를 발생하게 된다. Fig. 2의 (c)와 (d)는 이상의 조건으 로 합성된 피치 코팅된 흑연 잔유 화합물의 입자형태를 확인 하기 위한 전자현미경 사진이다. Fig. 2의 (c) 및 (d)에 나타난 것처럼 그 입자의 형태는 구형으로 비교적 균일한 형태를 나 타냈다. 흑연의 층간에 황산 잔유물을 형성시켜 리튬의 삽입 과 탈삽입을 원활하게 하고 단위질량당 리틈의 삽입량을 증가 시키고자 시도하였다.

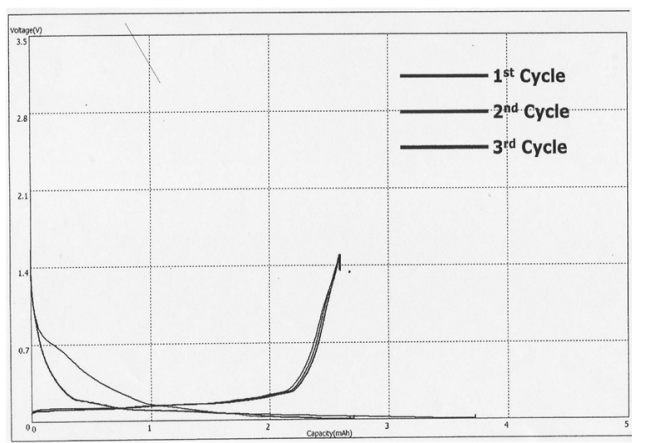

(b)

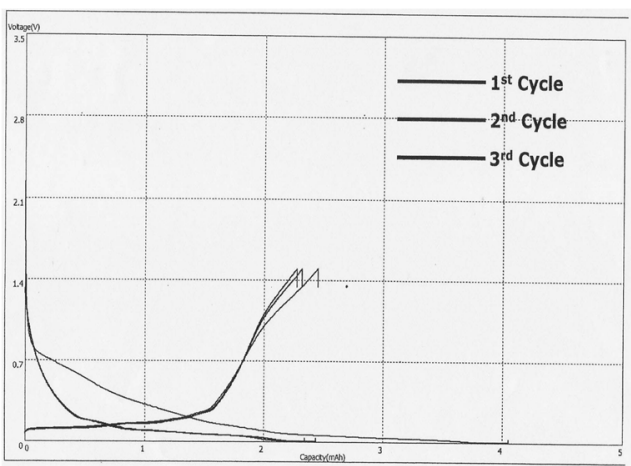

(d)

Fig. 3. The valuation of electrochemical charge-discharge characteristics; (a) natural graphite, (b) pitch-coated graphite, (c) amorphous graphite and (d) pitch-coated graphite residual compounds. 
제조된 흑연 잔유화물과 피치 코팅된 흑연 잔유화물 결정구 조 특성을 조사하기 위하여 시료의 X-선 회전분석을 실시하 였다. 흑연 잔유화물과 피치 코팅된 흑연 잔유화물의 X-선 회 절 분석값을 Table 4와 Table 5에서 각각 나타내었다. Table 4 와 Table 5에서 볼 수 있듯이 두 시료는 결정화도가 높은 것 을 볼 수 있으며, 거의 일치하는 회절각도 (20)를 나타내는 것 을 알 수 있었다. 또한, 피치 코팅된 흑연 잔유화물의 층간거 리 $\mathrm{d}_{002}$ 는 이론적인 흑연의 층간거리 $3.35 \AA$ 과 거의 일치한 것 을 확인할 수 있었다.

\section{2. 전기화학적 특성 평가}

본 연구의 특성은 결정화도가 낮은 흑연의 효율적인 이용을 기본 목적으로 두었다. 전기화학적 특성 평가에 관한 결과를 살펴보았을 때, 천연흑연, 피치 코팅된 흑연 잔유 화합물, 흑 연, 피치코팅된 흑연의 순서로 우수성이 나타났다. 천연흑연의 경우, 1 회의 사이클 용량은 다른 어떤 시료의 경우보다 높게 나타났으며, 단위 질량당 충방전 용량 역시 높게 나타났다. 그 러나 피치 코팅된 흑연 잔유 화합물의 경우, 단위 질량당 충 방전 용량이 가장 높게 나타났다. 이들 결과에 따라 충방전 효 율 역시 높은 값은 나타내고 있으며, 2 차전지의 음극물질로 유 력한 결과값을 보이고 있다. 이들에 결과값을 Fig. 3과 Table 6에 나타내었다. Table 6에 나타낸 피치 코팅된 흑연 잔유 화 합물의 경우 상당히 높은 효율을 나타내었으며, 충전 용량의 경우 $953 \mathrm{mAh} / \mathrm{g}$ 이었으며, 방전 용량의 경우 $757 \mathrm{mAh} / \mathrm{g}$ 이 고 역시 다른 시료와 달리 높은 결과값을 보였으며, 평균 충 방전 효율의 경우 $82.7 \%$ 의 결과를 얻었다. 그러나 비결정성 탄소재료인 petroleum cokes와 pitch cokes를 $1000^{\circ} \mathrm{C}$ 이하에 서 저온소성한 탄화물계에서는 이론적인 방전용량 $372 \mathrm{mAh} /$ $\mathrm{g}$ 을 넘는 전극재료들이 상당수 보고되고 있다[11, 13, 14]. $\operatorname{Dahn}$ 등 $[15,16]$ 은 “저온"-열처리온도 $\left(550^{\circ} \mathrm{C} \sim 1000^{\circ} \mathrm{C}\right)$ 에서의 pyrolysis에 의해 만들어진 soft와 hard carbon에 대해 0 2.5 V 사이의 전위에서 400 900 mAh/g의 가역성 capacity를 보인다

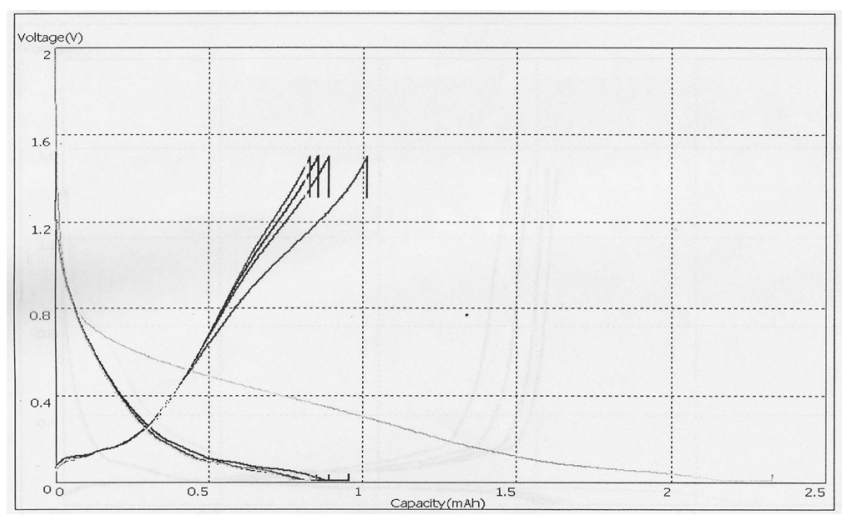

(a)

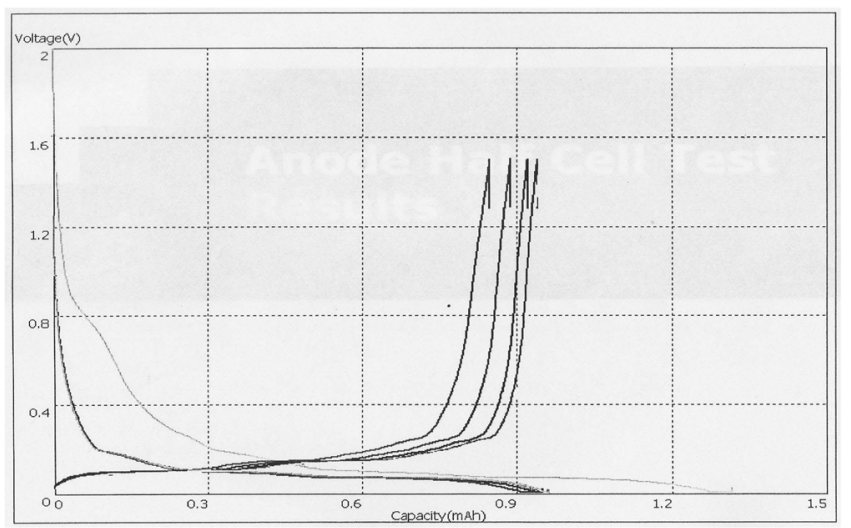

(b)

Fig. 4. Charge-discharge characteristics of the pitch-coated graphite residue compounds; (a) graphite 78 and (b) graphite 80 .

Table 6. Test results for the electrical properties

\begin{tabular}{|c|c|c|c|c|c|c|c|}
\hline \multirow{2}{*}{ Sample } & \multirow{2}{*}{$\#$} & \multirow{2}{*}{$\begin{array}{c}\text { Initial OCV } \\
\text { (V) }\end{array}$} & \multicolumn{2}{|c|}{ 1st Cycle Capacity [mAh] } & \multicolumn{3}{|c|}{ Specific Capacity $[\mathrm{mAh} / \mathrm{g}]$} \\
\hline & & & Charge & Discharge & Charge & Discharge & Efficiency \\
\hline \multirow{3}{*}{ Natural graphite } & 1 & 3.14 & 4.257 & 3.123 & 432 & 317 & $73.4 \%$ \\
\hline & 2 & 3.01 & 3.937 & 2.764 & 477 & 335 & $70.2 \%$ \\
\hline & 3 & 3.09 & 4.387 & 3.215 & 376 & 275 & $73.3 \%$ \\
\hline \multirow{3}{*}{$\begin{array}{l}\text { Pitch-coated } \\
\text { graphite }\end{array}$} & 1 & 3.10 & 3.955 & 2.690 & 420 & 286 & $68.0 \%$ \\
\hline & 2 & 1.71 & 3.730 & 2.599 & 394 & 274 & $69.7 \%$ \\
\hline & 3 & 2.51 & 3.314 & 2.230 & 383 & 258 & $67.3 \%$ \\
\hline \multirow{3}{*}{$\begin{array}{c}\text { Amorphous } \\
\text { graphite }\end{array}$} & 1 & 2.73 & 2.772 & 1.519 & 552 & 303 & $54.8 \%$ \\
\hline & 2 & 2.62 & 2.600 & 1.411 & 661 & 359 & $54.3 \%$ \\
\hline & 3 & 3.06 & 2.413 & 1.299 & 538 & 289 & $53.8 \%$ \\
\hline \multirow{3}{*}{$\begin{array}{l}\text { Pitch-coated } \\
\text { graphite residual } \\
\text { compounds }\end{array}$} & 1 & 2.43 & 3.935 & 2.377 & 953 & 757 & $79.4 \%$ \\
\hline & 2 & 2.94 & 3.860 & 2.325 & 732 & 608 & $83.1 \%$ \\
\hline & 3 & 2.45 & 4.043 & 2.452 & 868 & 744 & $85.7 \%$ \\
\hline
\end{tabular}


Table 7. Test results for the electrical properties

\begin{tabular}{ccccccc}
\hline & & Initial OCV & \multicolumn{2}{c}{ 1st Cycle Capacity [mAh] } & \multicolumn{2}{c}{ Specific Capacity [mAh/g] } \\
\cline { 3 - 7 } & & $(\mathrm{V})$ & Charge & Discharge & Reversible Capacity & Efficiency \\
\hline \multirow{2}{*}{ 토상흑연 78} & 1 & 3.00 & 2.326 & 1.016 & 698 & $63.7 \%$ \\
\hline \multirow{2}{*}{ 토상흑연 80} & 2 & 2.78 & 2.316 & 1.010 & 697 & $63.6 \%$ \\
& 2 & 2.64 & 1.315 & 0.848 & 685 & $74.5 \%$ \\
\end{tabular}

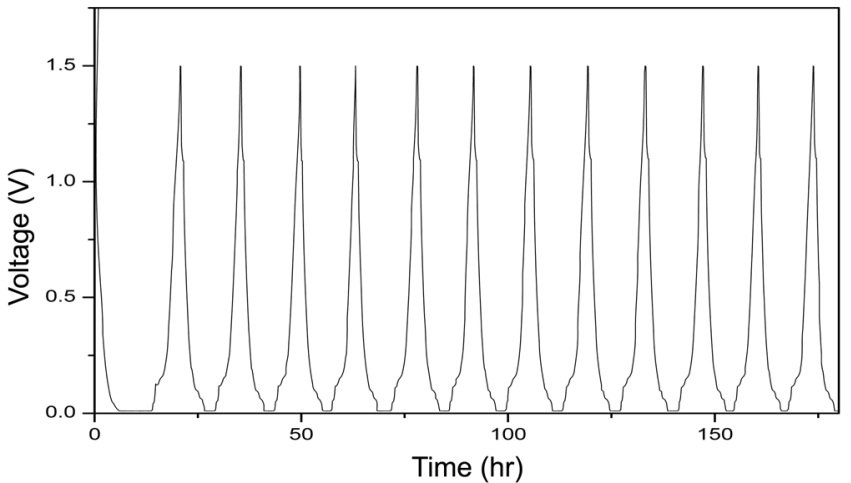

(a)

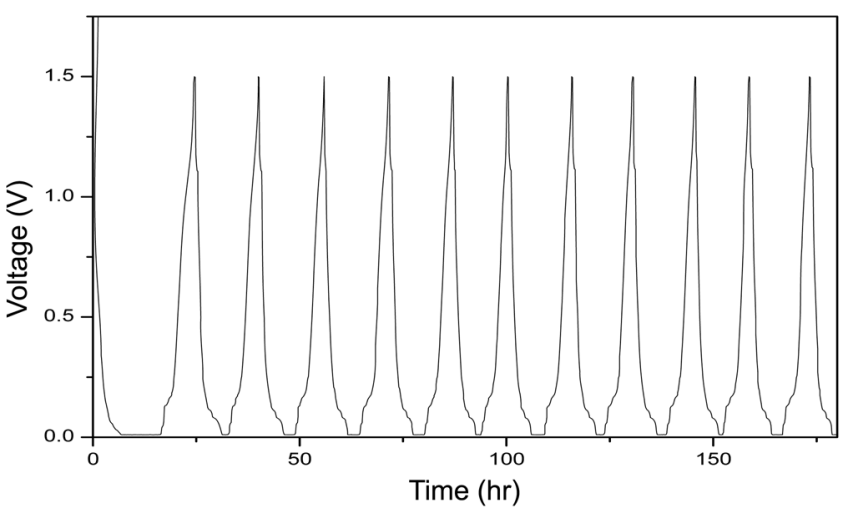

(b)

Fig. 5. 180 hours continual charge-discharge characteristics of the pitch-coated graphite residue compounds; (a) graphite 78 and (b) graphite 80.

고 하였다. 이는 Table 5에서 확인된 바와 같이 탄소의 층간거 리가 $3.3539 \AA$ 으로 이론적인 흑연의 층간거리인 $3.35 \AA$ 에 가 깝고 결정화도가 매우 높은 것을 알 수 있다. 따라서 높은 결 정화도를 자진 결정성계 탄소재료인 경우 흑연의 이론용량에 가까운 삽입량을 가지는 것을 확인할 수 있다. 또한 리틈의 삽 입시의 용량으로 표현되는 것에 비하여 탈삽입으로 표현되는 리튬의 용량은 큰 차이를 나타내고 있으며 이것은 리튬의 삽 입시에 여러 가지 요인[13-18]에 의하여 나타나는 지연시간에 의한 것으로 사료된다.

상기 결과로부터 우수한 특성을 나타낸 피치 코팅된 흑연

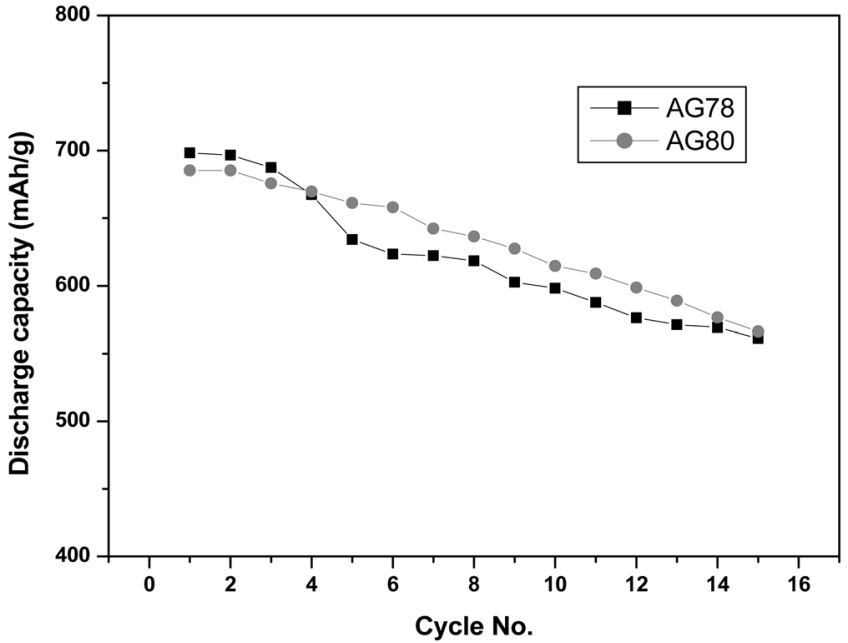

Fig. 6. 15 Relationships of cycle numbers and discharge capacity characteristics of the pitch-coated graphite residue compounds.

잔유 화합물을 선택하여 고정탄소량에 따라 (a)의 경우 고정 탄소함유량이 $78 \%$ 이상으로 “흑연 78”이라 명명하였으며, (b) 의 경우, 고정탄소함유량이 $80 \%$ 이상으로 “흑연 80 ”이라 각 각 명명하였다. Fig. 4와 Table 7은 충방전 특성에서 우수한 결 과를 보인 피치가 코팅된 흑연 잔유 화합물의 전기화학적 충 방전 특성 평가를 탄소함유량에 따른 시료에 따라 나타낸 것 이다. 두 가지 시료의 경우, 고정탄소량이 높은 “흑연 80"이 좋은 충방전 효율을 보였다. 그러나 Table 7에서 나타난 바와 같이, 용량에 효율값이 다소 떨어진 이유는 황산흑연 층간화 합물을 제조한 후에 장기간 방치로 인하여 황산잔유화합물의 흑연층사이에서 유출로 인하여 그 결과값이 다소 낮아진 것으 로 예상된다. 그러나, Fig. 5는 피치 코팅된 흑연잔유 화합물 의 180 시간 동안 연속 충방전 특성 평가를 나타낸 것이다. 두 가지 시료 모두 양호한 연속 충방전 특성을 보이고 있다. 이 들 결과에 따르면, 충방전의 안정성을 보이고 있으며, 2 차전지 의 부극재료로서 적합할 것으로 사료된다. 또한 이들 시료에 대한 방전 용량을 측정한 결과 Fig. 6과 같이 나타났다. 이들 결과에 따르면 “흑연 78”과 “흑연 80”의 경우 안정한 방전 용 량을 나타내었으며, 용량 저하율이 크게 떨어지지 않고 안정 성을 보였다. 


\section{4. 결 론}

본 연구는 저급 흑연을 사용하여 2차전지 음극재로서 특성 을 평가하였다. 천연흑연, 흑연, 피치코팅된 흑연 및 피치가 코 팅된 흑연 잔유화합물중 전기화학적 충방전 특성이 우수하게 나타난 피치가 코팅된 흑연 잔유화합물을 선택하여 주요한 특 성 평가 평가를 하였다. 평가의 응용방법으로 흑연에 황산을 삽입시키고, 이를 수세하여 잔유화합물을 얻었다. 이들 잔유 화합물에 석유계 피치를 사염화탄소를 사용하여 코팅하였으며 이들 결과는 코팅 효과가 상당히 우수하게 나타났다. 상기방 법에 의해 제조된 흑연 층간화합물 음극재료를 사용한 평균 충방전 효율의 경우 $82.7 \%$ 의 결과를 얻었다. 방전 용량 역시 다른 시료와 달리 높은 결과값을 보였다. 상기 방법으로 탄소 함량이 $78 \%$ 인 흑연과 $80 \%$ 인 흑연을 선택하여 피치가 코팅된 흑연 잔유화합물의 전기화학적 충방전 특성을 연구한 결과, 충 방전의 안정성을 보이고 있으며 2차전지의 음극재료로서 적합 한 결과를 나타내었다.

\section{참고문헌}

[1] Faul, I.; Knight, J. Chemistry \& Industry 1989, 18, 820.

[2] Ruetschi, P. J. Power Sources 1993, 42, 1.

[3] Miura, K,; Yamada, A.; Tanaka, M. Electrochimica Acta. 1996, 41, 249.

[4] Terasaki, M.; Yoshda, H.; Tukamoto, M.; Mizutani, M.; Yamachi, M. J. Electrochemical Soc., Jap. 1993, 12, 1471.

[5] Zhou, P.; Papanek, P.; Bindra, C.; Lee, R.; Fischer, J. E. J Power Source 1997, 296.

[6] Scrosati, B. J. Electrochem. Soc. 1992, 139, 2776.
[7] Barboux, P.; Tarascon, J. M.; Shokoohi, F. K. J. Solid State Chem. 1991, 94, 185.

[8] Kinoshita, K. "Electrochemical and Physicochemical Properties", John wiley \& Sons. Inc., Canada. 1988.

[9] Barnett, B. M.; Dowgiallo, E.; Halpert, G.; Matasuda, Y. "New Sealed Rechargeable Batteries and Supercapacitors", The Electrochemical Society, Inc., Proceeding Vol. 93-23, 1993, 206.

[10] Whittingham, M.; Allan, J.; Jacobson, R. Academic Press, 1982, 19.

[11] Maeda, Y:; Harada, S. Synthetic Materials 1989, 31, 389.

[12] Scrosati, B. "The Electrochemistry of Novel Material", ed., Lipkowski J and Ross PN. VCH Publishers Inc., New York, 1994, 111.

[13] Zheng, T.; Liu, Y.; Fuller, E. W.; Tseng, S.; Sacken, U.; Dahn, J. R. J. Electrochem. Soc. 1995, 142, 2581.

[14] Frankin, R. E. Proc. Roy. Soc. 1951, A209, 196.

[15] Dahn, J. R.; Sleigh, A. K.; Shi, H.; Reimers, J. N.; Zhong, Q.; Way, B. M. Electrochem. Acta. 1993, 38, 1179.

[16] Dahn, J. R.; Sleigh, A. K.; Shi, H.; Way, B. M.; Weydanz, W. J.; Reimers, J. N.; Zhong, Q.; von Sacken, U. "Carbons and graphites as substitutes for the lithium anode in lithium batteries: New materials, developments and perspectives", In: Pistoia, G. ed. Industrial chemistry library. Vol. 5, London: Elsevier 1993.

[17] Osaka, T.; Datta, M. ed. "Energy storage systems for electronics", Gordon and Breach Science Publishers, The Netherlands, 2000.

[18] Sato, K.; Nogouchi, M.; Demachi, A.; Oki, N.; Endo, M. Science 1994, 264, 556. 